DOI 10.37882/2223-2974.2021.02.24

\title{
НЕКОТОРЫЕ КРИМИНОЛОГИЧЕСКИЕ АСПЕКТЫ ЖЕСТОКОГО ОБРАЩЕНИЯ С ДЕТЬМИ
}

\section{SOME CRIMINOLOGICAL ASPECTS OF CHILD ABUSE}

I. Filimonov

Summary: The article is devoted to criminological characteristics of such a socially dangerous act as child abuse. Special attention is paid to the identity of the criminal, as well as the reasons and conditions that contribute to the Commission of these criminal manifestations.

Keywords: crimes against minors, criminological characteristics, criminal personality, crime prevention, violent crimes.
K онституция РФ признает права и свободы человека и гражданина высшей государственной ценностью. Достоинство личности охраняется государством, недопустимы пытки или иное насилие, которое унижает человеческое достоинство[1]. Эти правила распространяется на всех граждан, включая детей. Однако, дети несмотря на существование различных правил и законодательных норм, не могут быть в полной мере защищены от насилия. Множество преступлений против детей, предусматривающие ответственность по ст. 156 УК РФ[2], остаются нераскрытыми. Латентность данных преступлений обусловлена с тем, что дети подвергаются насилию со стороны собственных родителей, которые должны их защищать и оберегать, соответственно, заявить о совершенном преступлении попросту некому.

Преступность в семье является одной из наиболее распространенных и социально опасных форм агрессии, поскольку около 30-40\% всех тяжких насильственных преступлений совершается именно в семье. Ежегодно около 2 млн. детей в возрасте до 14 лет избиваются родителями, более 50 тыс. из них уходят из дома, опасаясь жестокого обращения, а около 25 тыс. находятся в розыске, как без вести пропавшие. Согласно официальным статистическим данным, ежегодно в России совершается около 90 тысяч преступлений против несовершеннолетних[5], что составляет примерно 5 \% от общего числа регистрируемых преступлений[6].

Если рассматривать статистику совершаемых преступлений против несовершеннолетних, то можно констатировать, что неисполнение обязанностей по воспитанию несовершеннолетнего не является самым часто совершаемым видом преступления, а занимает лишь от 2 до 5 \%. При этом, наблюдается тенденция к снижению зарегистрированных преступлений по ст. 156 УК РФ.
Филимонов Иван Анатольевич

К.ю.н., дочент, Владивостокский филиал Дальневосточного юридического института МВД России 178303@mail.ru

Аннотация: Статья посвящена криминологической характеристике такого общественно-опасного деяния, как жестокое обращение с детьми. Отдельное внимание уделено личности преступника, а также причинам и условиям, способствующим совершению данных преступных проявлений.

Ключевые слова: преступления против несовершеннолетних, криминологическая характеристика, личность преступника, профилактика преступлений, насильственные преступления.

Так, если в 2010 году количество зарегистрированных преступлений по данной статье составляло 4757, то к 2019 году эта цифра упала до 1491, то есть более, чем в три раза.

Личность преступника, как один из элементов криминологической характеристики можно условно разделить на два вида - это родители (опекуны), а также иные лица. Статистика свидетельствует о том, что виновниками жестокого обращения с детьми чаще всего являются родители (94.2\%), из них $85 \%$ - родные родители. Родные матери виновны в плохом обращении и уходе почти в 2 раза больше, чем отцы (75\% против 41\%)[3].

Для родителей несовершеннолетних, ставших жертвами неисполнения или ненадлежащего исполнения обязанностей по их воспитанию, свойственно практически в своем абсолютном большинстве ведение асоциального образа жизни, что уже в значительной степени характеризует условия совершения ими подобных преступлений. Лица, ведущие отрицательно направленный социальный образ жизни, являются склонными к систематическому злоупотреблению алкоголем, реже наркотиками, безусловно, приводящему, в первую очередь, к нарушению нормального функционирования семьи, разрушению ценных семейных связей, а значит и надлежащей обстановки, в которой должен развиваться ребенок. В условиях алкоголизма и наркомании личность деградирует, ее взаимодействие с «благополучными» слоями общества замещается на общение с маргинальными членами общества присутствием которых зачастую сопровождается попустительское отношение родителей к ребенку по месту его проживания[4].

Такие семьи характеризуются отсутствием материального достатка или низким уровнем дохода, безрабо- 
тицей, социальной изоляцией и закрытостью, нередко многодетностью.

С психологической точки зрения для преступниковродителей характерен низкий образовательный уровень, обусловленный невысоким интеллектом человека, а также трудности социальной адаптации, вызванные пониженной эмоциональной устойчивостью, приводящие, в свою очередь, к чрезмерной импульсивности, агрессивности, формирующим через призму деформации человеческих ценностей тип насильственного поведения такой личности. Лиц с подобной характеристикой отличает низкий уровень культуры, отношений и поведения, примитивность интересов и ценностных ориентаций, отсутствие устойчивых жизненных планов и желания к выполнению своих гражданских обязанностей, вразрез которым им свойственна устойчивая отрицательная и безразличная позиция к необходимости трудиться, заботиться о надлежащем воспитании своих детей[4].

К числу установок, дискредитирующих работу лица, занятого по роду своей профессиональной деятельности воспитанием несовершеннолетних, и формирующих у работников преступную направленность в осуществлении этой деятельности, в первую очередь, на наш взгляд, относится отсутствие должного социального контроля или его низкий уровень, являющийся одним из качественных показателей микросреды, в условиях которой совершается рассматриваемое нами преступление. Так, в различных специальных учебно-воспитательных и медицинских учреждениях работа персонала с несовершеннолетними носит закрытый для посторонних лиц характер, и подобное своеобразное невмешательство в ход воспитательного процесса порождает определенное ощущение безнаказанности и бесконтрольности за уровнем «педагогичности» воспитательного воздействия, оказываемого на несовершеннолетних. Низкий же уровень социального контроля, помимо внешних проверок, в том числе, может выражаться и в преступном, попустительском отношении руководства учреждения к недопустимым методам воспитания со стороны его работников[4].

В описанных условиях микросреды совершения рассматриваемого преступления ее совокупная взаимосвязь с психологической неустойчивостью работника порождает ту самую кризисную для него ситуацию, в условиях которой личность оказывает свое преступное воздействие на несовершеннолетнего. Сложившиеся социальные условия всегда проявляются в преступлении, преломляясь через личность. В данном случае, на наш взгляд, указанное преломление проявляется в так называемом психологическом «эффекте выгорания», когда труд, скажем педагога с большим стажем работы, относящийся к числу эмоционально-напряженных, требующих каждодневного самообладания и саморегуляции, приводит к «профессиональной» усталости, ослаблению коммуникативных навыков, побуждающих в очередной стрессовой ситуации с ребенком применение в отношении него непедагогических методов воздействия.

Характеристика личности, будучи многогранной системой свойств и признаков, их содержания и многообразного сочетания, раскрывает наиболее полное представление о тех, кто совершает данное преступление, их мотивации и условиях противоправного поступка, а значит, и о наиболее рациональных способах взаимодействия с рассмотренной категорией преступников в процессе производства по уголовному делу. Знание о личности преступника позволяет найти способ взаимодействия с ним на этапе предварительного следствия и дознания, а также помогает понять причины и условия совершения преступления.

Таким образом, можно говорить о достаточно низком проценте совершения преступлений, связанных с жестоким обращением с несовершеннолетними - это 2\% от всех совершаемых преступлений в отношении несовершеннолетних или чуть менее 1,5 тысяч регистрируемых заявлений за прошлый год. При этом, не стоит забывать о высокой латентности преступлений данной категории.

Личность преступника является одним из важнейших криминологических объектов изучения. По делам о неисполнении или ненадлежащем исполнении обязанностей по воспитанию несовершеннолетнего личности делятся на две категории - это родители и педагоги (иные работники, чья деятельность непосредственно связана с воспитанием или надзором за несовершеннолетними).

В первом случае личность преступника носит асоциальный характер, как правило, это лица с отсутствием постоянного заработка, вредными привычками, примитивными интересами и, соответственно, низким уровнем интеллекта, что обуславливает повышенную агрессию и деформацию морально-этических принципов воспитания.

Лица, относящиеся ко второму типу личности преступника, привлекаемого к уголовной ответственности по ст. 156 УК РФ, напротив, имеют высшее, либо среднее образование в области педагогики или медицины (в зависимости от рода деятельности). Им, отнюдь, не свойственны вышеуказанные качества. Для лиц, которые совершают данные деяния, границы допустимого поведения не стерты, однако им свойственна профессиональная деформация, следствие которой и выражается в преступном поведении.

Неисполнение обязанностей по воспитанию несовершеннолетнего является порождением многих причин и факторов, к которым относятся как внешние 
социальные факторы, так и внутрисемейные, причем последние являются определяющими. Чаще всего причиной совершения преступлений является употребление алкоголя, что стирает границы доступного и способствует к порождению конфликтных ситуаций в семье, сопровождающегося агрессией по отношению к более слабым членам семьи, в том числе и несовершеннолетним. Не стоит забывать и о том, что жестокое обращение с детьми осложняется проблемой виктимности. Жестокому обращению могут быть подвергнуты дети любого возраста, однако для малолетних данные действия мо- гут привести к более губительным последствиям в виде причинения тяжкого вреда здоровью или даже смерти. Жестокое обращение с детьми наносит неизгладимое впечатление на психику ребенка, приводит к его агрессивному поведению среди сверстников, провоцирует совершение в дальнейшем преступлений, а также может привести к различным психическим расстройствам. Проблема жестокого обращения с детьми, по-нашему мнению является одной из главных проблем общества, поэтому важно обратить повышенное внимание на профилактику указанных видов деяний.

\section{ЛИТЕРАТУРА}

1. Конституция Российской Федерации: принята всенародным голосованием 12.12.1993: с учетом поправок, внесенных законами Рос. Федерации о поправках к Конституции Рос. Федерации от 30.12.2008 № 6-ФК3, от 30.12.2008 № 7-ФК3, 0т 05.02.2014 № 2-ФК3, от 21.07.2014 № 11-ФК3, 0т 14.03.2020 № 1-ФКЗ // Рос. газ. 2020. 4 июля.

2. Уголовный кодекс Российской Федерации: федер. закон от 13.06.1996 № 63-Ф3: ред. от 31.07.2020. Доступ из справ.-правовой системы «КонсультантПлюс».

3. Грицай А.Г., Спирина В.И. Физическое насилие в семье как одна из форм жестокого обращения с детьми // Вестник адыгейского государственного университета. Серия 3: Педагогика и психология. 2011. №1. С. 27.

4. Худицкая Ю.П. Криминалистические аспекты изучения типичной личности преступника по делам о неисполнении или ненадлежащем исполнении обязанностей по воспитанию несовершеннолетнего (СТ. 156 УК РФ) // Ученые записки Комсомольского-на-Амуре государственного технического университета. 2014. Т. 2. № 2 (18).

5. Электронный ресурс: Федеральная служба государственной статистики. [Электронный ресурс]. URL: https://www.gks.ru/folder/13807 Дата обращения: 07.10.2020.

6. Электронный ресурс: Состояние преступности январь-декабрь 2019 года // МВД России [Электронный ресурc]. URL: https://xn--b1aew.xn--p1ai/ reports/11/ Дата обращения: 07.10.2020

(с Филимонов Иван Анатольевич (178303@mail.ru). 